\title{
Quantitative Analysis of Mineral Elements in Commercial Pineapple Juices by Inductively Coupled Plasma Mass Spectrometry (ICP-MS)
}

\author{
Alassane Youssao Abdou Karim ${ }^{1,}$, , Magloire Akakpo Nonvignon Gbaguidi ${ }^{1}$, Oriol Baltrons ${ }^{3}$, \\ Fabienne Seby $^{3}$, Mathilde Monperus ${ }^{3}$, Henri Houénoukpo Soclo ${ }^{1}$, Olivier Donard ${ }^{2,3}$ \\ ${ }^{1}$ Department of Chemical Engineering-Processes, Polytechnic School of Abomey-Calavi, University of Abomey, Calavi, Bénin \\ ${ }^{2}$ Ultra Trace Analysis Aquitaine (UT2A), University of Pau and Pays de l'Adour (UPPA), Pau, France \\ ${ }^{3}$ Multidisciplinary Institute of Research on Environment and Materials (IPREM 12- UMR 5254), University of Pau and Pays de l'Adour \\ (UPPA), Pau, France
}

\section{Email address:}

youssaoalassane@gmail.com(A.Y.A.Karim),gbmag3@gmail.com(M. A. N. Gbaguidi), oriol.baltrons@univ-pau.fr(O.Baltrons), Fabienne.seby@univ-pau.fr(F.Seby),Mathilde.monperus@univ-pau.fr(M.Monperus),henrisoclo@yahoo.fr(H.H. Soclo),

Olivier.donard@univ-pau.fr(O.Donard)

${ }^{*}$ Corresponding author

\section{To cite this article:}

Alassane Youssao Abdou Karim, Magloire Akakpo Nonvignon Gbaguidi, Oriol Baltrons, Fabienne Seby, Mathilde Monperus, Henri Houénoukpo Soclo, Olivier Donard. Quantitative Analysis of Mineral Elements in Commercial Pineapple Juices by Inductively Coupled Plasma Mass Spectrometry (ICP-MS). International Journal of Food Science and Biotechnology. Vol. 3, No. 2, 2018 , pp. 60-69. doi: $10.11648 /$ j.ijfsb.20180302.14

Received: April 1, 2018; Accepted: April 17, 2018; Published: May 21, 2018

\begin{abstract}
The consumption of fruit juice in the diet has increased in recent years because it contains mineral food supplements and other essential vitamins. In this study, sugar levels and mineral nutrient concentrations were evaluated in 92 commercial pineapple juice samples from Benin and France using inductively coupled plasma mass spectrometry (ICP-MS). The analysis of the data obtained reveals three ranges of concentrations relative to major elements or macro-elements (Ca, $\mathrm{Mg}$ ), to minor elements or micro-elements ( $\mathrm{Mn}, \mathrm{Fe}, \mathrm{Ni}, \mathrm{Cu}, \mathrm{Zn}$ ), and to trace elements (Mo, V, Co, Cr). The concentrations of macro-elements and micro-elements (expressed in $\mu \mathrm{g} / \mathrm{L}$ ) vary from 11333 to 278000 for $\mathrm{Mg}, 95200$ to 788000 for Ca, 536 to 25344 for $\mathrm{Mn}, 142$ to 85612 for Fe, 5 to 253 for Ni, 5 to 1256 for $\mathrm{Cu}$, and from 43 to 25862 for Zn. The trace elements were found in the concentration ranges (expressed in $\mu \mathrm{g} / \mathrm{L}$ ) of: 0.23 - 12.50 for Vanadium, 0.58 - 17.10 for Cobalt, 1.17 - 58.70 for Molybdenum and finally $4-70.5$ for Chromium. The sugar levels in the various commercial juices collected in Benin and France vary from 11.0 to 18.5 Brix with an average value of 14.0 Brix. Apart from the heterogeneous nature of the juices produced in Benin production units, mineral and sugar levels were generally in accordance with international standards such as CODEX STAN 182-1993. The transformation of pineapple into fruit juice is a credible alternative for the improvement of pineapple exports, if the marketing strategy is better adapted and the local authorities support the manufacturers of the production chain to improve the quality of juices and highlight their excellent nutritional quality.
\end{abstract}

Keywords: Minerals, Juice, Pineapple, Benin, France, Codex Stan, ICP-MS

\section{Introduction}

Two varieties of pineapple, namely "Cayenne smooth" and "Sugarloaf", are known to be produced in Benin Republic. The vegetative cycle of pineapple covers a period from 15 to 24 months with their production being concentrated in the southern and central regions of the country, representing $10 \%$ of the territorial area inhabited by nearly $60 \%$ of the population [1]. Furthermore, an increase in the production and consumption of pineapple has been observed aided by the extension of its cultivation in new geographical areas of the country coupled with the increase in cross-border flows, through informal transactions, to neighbouring countries such as Nigeria, Burkina Faso and Niger. For instance, earlier in 20016, it contributed $1.2 \%$ to the Gross Domestic Product 
(GDP) and 4.3\% to agricultural GDP, or about 13 billions FCFA [1]. Apart from cotton and cashew with higher export potential, pineapple is another crop that can be exported. This is one of the reasons why the government of Benin Republic, in its strategy to fight against poverty, has made the revival of the agricultural sector one of its priorities.

Concerning pineapple, the goal is to increase substantial production of high quality crops and improve the marketing of the fresh fruits and its by-products in order to contribute to the diversification of exports [2]. Despite this renewed interest in this sector in Benin, in terms of its potential socioeconomic and financial benefits, that part that has to do with pineapple is facing a number of challenges such as those related to the competitiveness of the commodity in terms of finished products meeting the standard requirements, especially the knowledge of nutritional value, for international market. Consequently, this study was carried out to investigate the concentrations of some minerals in extracted and bottled pineapple juices in Benin in comparison with those for other branded pineapple juices purchased from shopping outlets in France.

\section{Materials and Methods}

\subsection{Sampling of Juices}

Samples of pineapple juice were obtained from different processing units in Benin taking into cognisance place and dates of production, nature of the juice (cocktail or pineapple juice), the species of pineapple fruit (Cayenne smooth, Sugarloaf), etc. Samples of packaged and branded juice were also obtained from supermarkets in Pau, France for the purpose of comparison. A total of 85 samples of juice and a sample of pineapple syrup were obtained in Benin with 6 other pineapple juices purchased from supermarket in France were analysed. These samples were classified according to the different criteria that could influence the quality of juice. The inscriptions on the labels on the bottles containing the juice show several varieties but all Benin juices were natural without additives or additions of preservatives or sugar. All the samples for laboratory analyses were properly coded for easy identification. The location of transformation units and cultivation areas of pineapple are shown in figure 1 below.

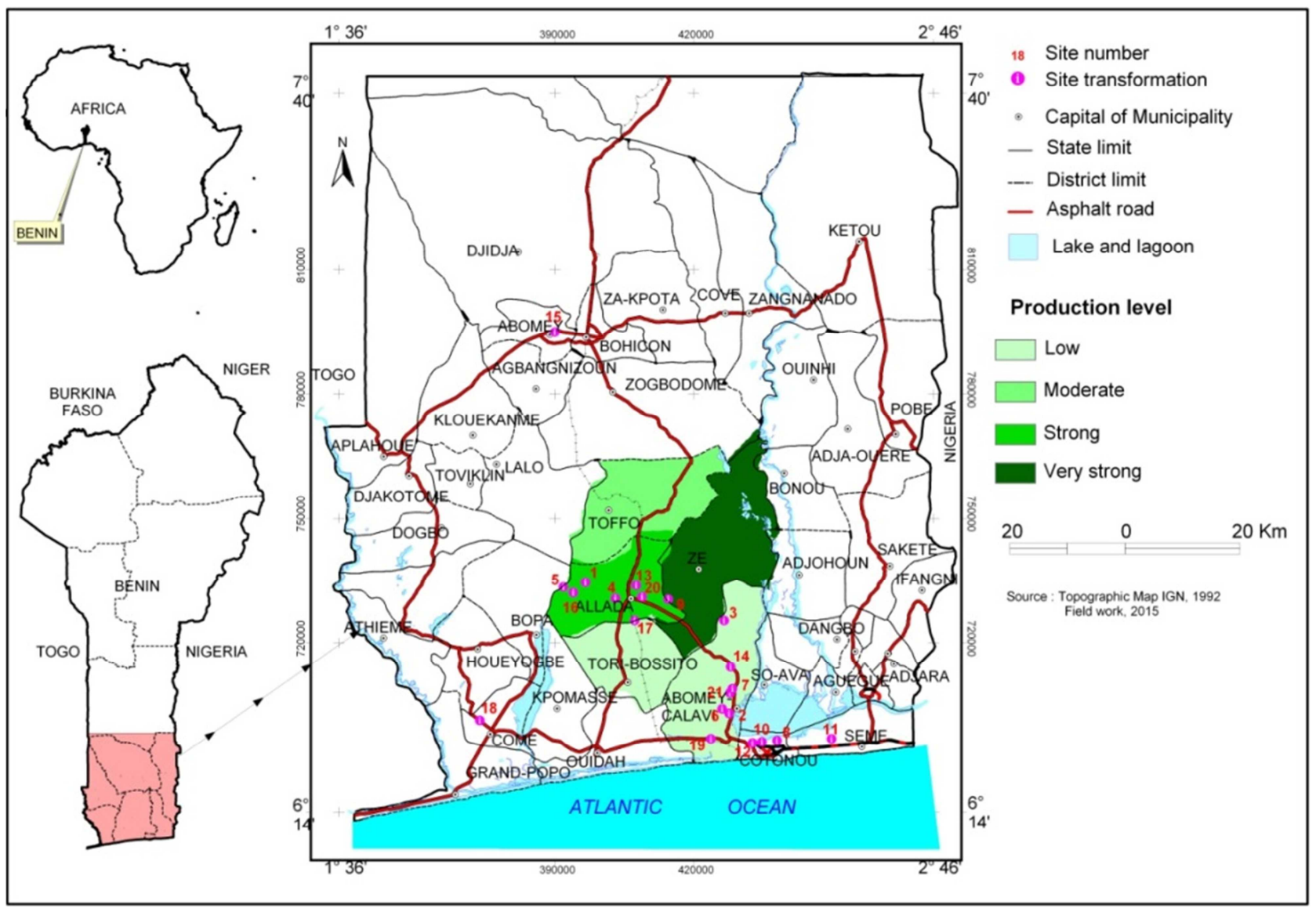

Figure 1. Location of growing areas of pineapple and juices production units in Benin.

The distribution of juices according to the nature of the fruit (pineapple and/or watermelon) gives us three groups namely: 100\% pineapple juice (84 samples), PAS Pineapple and Watermelon cocktail (5 samples) and FRE cocktail (3 samples).

\subsection{Choice of Sample Mineralization and Quantification Method}

The processing of juice samples for the determination of concentrations depends on the chemical forms concerned 
(soluble, total, species derived from the mineral element) and the mineral elements. Different authors have used hydrostatic atomic fluorescence spectrometry [3], optical emission spectrometry with an inductively coupled plasma source [3] or mass spectrometry inductively coupled plasma source (ICP-MS) [3, 4, 5, 6] without special treatment of samples other than dry or wet incineration for determination of chemical elements in juices. In this study, juice samples were mineralized to destroy organic matter [3] due to high viscosity and high content of dissolved solids; this made it possible to avoid non-spectral difficulties (mainly matrix effects) and spectral interferences in the spectrometric measurements. Digestion of the fruit juice samples was done by DigiPrep digestion blocks with concentrated nitric acid $\left(\mathrm{HNO}_{3}\right)$ and $30 \%$ hydrogen peroxide $\left(\mathrm{H}_{2} \mathrm{O}_{2}\right)$ [5] in a programmable oven with two levels of temperature (45 $\mathrm{C}$ and 90 C). An ELAN DRC Perkin Elmer apparatus equipped with a nebulizer was used with a Meinhart silica cyclonic chamber for spraying and continuous nebulization. The operating conditions were optimized daily using a standard 8level aqueous solution (for calibration of the apparatus) containing: $0 ; 0.05 ; 0.1 ; 0.5 ; 1 ; 5 ; 20$ and $100 \mathrm{ppb}$ and internal standards for the control of isotope intensities. The internal standards used were indium (In), bismuth (Bi) and scandium (Sc) with $5 \mathrm{ppb}$ concentrations. Two types of reference materials (SRM NIST 1640a and SRM SLRS-5) were used to determine the percentages of recuperation.

First, we used the semi-quantitative method available with Perkin-Elmer ICP-MS instrumentation (Perkin-Elmer total Quant III) which allowed us to identify the levels of concentrations in juices from Benin and juices purchased in supermarkets in France. After, we use the quantitative method to detect the real contamination level of our samples. The method of analysis was "Total Quant": this is a unique software feature for ELAN ICP-MS systems to quantify 81 elements in a sample by interpreting the full mass spectrum. Total Quant is an ideal tool for semi-quantitative analysis during the development of the method; it is also used for the characterization of the final material. When using Total Quant, the spectral interpretation is performed automatically by the software, and the intensities were assigned to elements after correction of the interference on the individual isotopes. The intensities were compared to a stored response table to convert them into concentrations. Total Quant gives quantitative results typically $+/-25 \%$ of the real value in simple matrices.

This precision has been improved by the use of an external standard that corrects the "response table" used by the software. Internal standards, added to the sample and standard solutions, are mainly used in measurements made by plasma-based instruments to compensate for possible variations in ICP-MS performance.

\subsection{Statistical Analysis}

Statistical analyses were carried out with the aid of Statistical Package for Social Science (SPSS) Version 20.0 and Minitab Version 16.0. The statistical tools were those for calculation of the dispersion characteristics and plotting of the moustache boxes and logit including analysis of variance. The data were pre-processed using the whisker boxes to identify recording errors and concentration differences between different processing units.

\section{Results and Discussion}

\subsection{Sugar Levels in Pineapple Juice}

Small producers in Benin are presently struggling to meet the criteria set for standard products particularly for export. This can be seen in the fact that the yields and volume of pineapple were high but less than $2 \%$ of the pineapple produced is exported [4]. It is important to state that the conversion of pineapple into fruit juice is an opportunity for producers from Benin to be able to export more pineapple in strict compliance with standards, in this case, the sugar levels expressed in Brix degree. The amount of sugar was determined using a prism from the refractive index. It expresses the amount of dry matter (in grams) per 100 grams of liquid. According to French Directive 93/77 of 21 September 1993 and CODEX STAN 247-2005, the minimum and maximum sugar levels in Brix degree of a commercial pineapple juice were 12.1 and 12.8 respectively. For Citrullus lanatus watermelon juice, the minimum sugar level in Brix degree is 8.0 (CODEX STAN 247-2005). In practice, corrected Brix is used which takes into account that juice acids do not contribute exactly to Brix in the same way as pure saccharose. But in a first approximation, we evaluated the contents without this correction for pineapple juices.

For juice comparison purposes, we determined the sugar content of pineapple juices sampled in manufacturing units in Benin and some samples purchased in supermarkets in France. For all these juices, the average total solid content was 14.0 Brix (Table 1), which was above 12.8 Brix, the international reference value. According to the results of the 92 samples presented in the following Table 1, the sugar levels vary from 11.0 to 18.5 Brix.

Table 1. Dispersal characteristics of total dissolved solids levels (sugar) in pineapple commercial juices.

\begin{tabular}{|c|c|c|c|c|c|c|c|}
\hline \multirow{2}{*}{ Variable (Brix) } & \multirow{2}{*}{ Mean value } & \multirow{2}{*}{ SD } & \multirow{2}{*}{ Minimum } & \multirow{2}{*}{ Maximum } & \multicolumn{3}{|c|}{ Percentiles } \\
\hline & & & & & 25 & 50 & 75 \\
\hline Total dissolved solids & 14.0 & 1.8 & 11.0 & 18.5 & 13.0 & 15.0 & 15.0 \\
\hline
\end{tabular}

SD: Standard Deviation

These results are in agreement with those of Miele et al., (2014) [2] for grape juices produced by biological processes.
The first quartile was 13.0 , which means that at least $75 \%$ of the samples have a sugar concentration higher than Codex 
Standard (CODEX STAN 247-2005) for pineapple juice, and the corresponding standards (8 Brix). all the watermelon-based juices are also in compliance with

Table 2. Average total dissolved solids (sugars) in commercial pineapple juice and syrup per unit (Brix).

\begin{tabular}{llllllllllll}
\hline Unit & ALA & ALO & BRA & CHA & FRE & FRU & INN* & JAF* & JUA & JUD & JUS \\
\hline Rate & 14.2 & 15.2 & 14.7 & 14.7 & 11.8 & 14.1 & 11.3 & 12.3 & 14.8 & 15.2 & 13.7 \\
Unit & $J U V$ & $L A S$ & OJA & $P A S$ & $S A N$ & $S I R^{* *}$ & $T R O$ & $V I B^{*}$ & $V I P$ & $V I T$ & $M E A N$ \\
Rate & 12.7 & 13.3 & 13.4 & 12.1 & 16.0 & 12.6 & 15.2 & 11.3 & 13.1 & 15.3 & 14.0 \\
\hline
\end{tabular}

* Juices from France ** Syrup $\mathrm{R}^{2}$ (Adjusted) $=54.07 \% \mathrm{p}<0.001$.

All the units produce juices according to the international standards in the matter with the exception of the FRE, VIB and INN juices, which have (unadjusted) rates slightly lower than the standards because of the dilution of the French commercial juices (Table 2). Also, according to that standard, fruit juices and nectars must have the characteristic colour, aroma and flavour of the juice of the variety of fruit from which they were obtained. This requirement is also satisfied for pineapple juices made in Benin and those obtained from French supermarkets.

\subsection{Concentration Ranges of Minerals in Commercial Juices}

The results in Tables 3 and 4 shows three ranges of concentrations. These are: major elements or macro-elements $(\mathrm{Ca}$, $\mathrm{Mg}$ ), minor elements or micro-elements ( $\mathrm{Mn}, \mathrm{Fe}, \mathrm{Ni}, \mathrm{Cu}, \mathrm{Zn}$ ) and trace elements (Mo, V, Co, Cr). However, the exploratory factor analysis identified four groups of variables that covariate with two representations that gather the parameters into two main groups, namely macro and micro-elements on one side and trace elements and degree Brix on the other side.

Table 3. Concentration ranges $(\mu \mathrm{g} / \mathrm{L})$ of major minerals and micro-elements in pineapple juice and syrup.

\begin{tabular}{|c|c|c|c|c|c|c|c|}
\hline & \multicolumn{7}{|l|}{ Variables $(\mu \mathrm{g} / L)$} \\
\hline & $M g$ & $\mathrm{Ca}$ & $M n$ & $\mathrm{Fe}$ & $\mathrm{Ni}$ & $C u$ & $Z n$ \\
\hline Average & 193558 & 223616 & 9551 & 5811 & 80 & 341 & 1313 \\
\hline SD & 36443 & 105092 & 4960 & 15809 & 38 & 151 & 3152 \\
\hline Minimum & 111333 (JAF1) & $\begin{array}{l}95200 \\
\text { (JAF2) }\end{array}$ & 536 (VIP3) & 142 (VIT5) & $\begin{array}{l}5 \\
\text { (VIP3) }\end{array}$ & $\begin{array}{l}5 \\
\text { (VIP3) }\end{array}$ & 43 (VIP3) \\
\hline $\begin{array}{l}\text { Maximum } \\
\text { Percentiles }\end{array}$ & 278000 (JUA1) & 788000 (JUD3) & 25344 (FRU5) & 85612 (OJA1) & 253 (OJA3) & 1256 (JUS2) & 25862 (JUD3) \\
\hline 50 & 201000 & 219500 & 8707 & 1861 & 80 & 325 & 712 \\
\hline 75 & 210750 & 252500 & 11904 & 2606 & 96 & 418 & 969 \\
\hline
\end{tabular}

All major and trace elements have concentrations above the quantification threshold with the exception of vanadium contained in 14 samples (Table 4) the concentrations which were below the quantification threshold corresponding to about $25 \%$ of the samples (1st quartile). Metal concentrations in fruit juice samples varied widely depending on the units that produced them (Table 3 and 4). Concentrations ranged from $11333 \mu \mathrm{g} / \mathrm{L}$ (JAF1) to $278000 \mu \mathrm{g} / \mathrm{L}$ (JUA1) for $\mathrm{Mg}$, from $95200 \mu \mathrm{g} / \mathrm{L}(\mathrm{JAF} 2)$ to $788000 \mu \mathrm{g} / \mathrm{L}$ (JUD3) for $\mathrm{Ca}$, from $536 \mu \mathrm{g} / \mathrm{L}$ (VIP3) to $25344 \mu \mathrm{g} / \mathrm{L}$ (FRU5) for Mn, from $142 \mu \mathrm{g} / \mathrm{L}$
(VIT5) to $85612 \mu \mathrm{g} / \mathrm{L}$ (OJA1) for Fe, from $5 \mu \mathrm{g} / \mathrm{L}$ (VIP3) to $253 \mu \mathrm{g} / \mathrm{L}\left(\mathrm{OJA}_{3}\right)$ for $\mathrm{Ni}$, from $5 \mu \mathrm{g} / \mathrm{L}\left(\mathrm{VIP}_{3}\right)$ to $1256 \mu \mathrm{g} / \mathrm{L}$ $\left(\mathrm{JUS}_{2}\right)$ for $\mathrm{Cu}$ and from $43 \mu \mathrm{g} / \mathrm{L}\left(\mathrm{VIP}_{3}\right)$ to $25862 \mu \mathrm{g} / \mathrm{L}\left(\mathrm{JUD}_{3}\right)$ for $\mathrm{Zn}$. These strong variations explain the high values obtained for standard deviation for $\mathrm{Zn}$. The mean concentrations obtained show the predominance of $\mathrm{Ca}$ with an average value of $223616 \mu \mathrm{g} / \mathrm{L}$ followed by $\mathrm{Mg}$ with an average concentration of $193558 \mu \mathrm{g} / \mathrm{L}$. Mean concentrations of $\mathrm{Mn}, \mathrm{Fe}, \mathrm{Ni}, \mathrm{Cu}$ and $\mathrm{Zn}$ were 4960, 15809, 38, 151 and $3152 \mu \mathrm{g} / \mathrm{L}$ respectively.

Table 4. Concentration ranges $(\mu \mathrm{g} / L)$ for trace elements in pineapple juices and syrups.

\begin{tabular}{|c|c|c|c|c|c|}
\hline Parameters & & $\mathbf{V}$ & $\mathrm{Cr}$ & Co & Mo \\
\hline \multirow{2}{*}{ Number of samples } & Valid* & 78 & 90 & 92 & 92 \\
\hline & Not detected & 14 & 2 & 0 & 0 \\
\hline Average & & 1.23 & 18.26 & 5.94 & 24.74 \\
\hline SD & & 1.85 & 15.99 & 2.56 & 13.25 \\
\hline Minimum & & 0.23 & 1.40 & 0.58 & 1.17 \\
\hline Maximum & & 12.50 & 70.50 & 17.10 & 58.70 \\
\hline \multicolumn{6}{|l|}{ Perentiles } \\
\hline & 50 & 0.69 & 13.10 & 5.61 & 19.05 \\
\hline & 75 & 1.22 & 22.53 & 6.87 & 31.88 \\
\hline
\end{tabular}

*Samples with concentrations below the limit of quantification were not considered in the statistical analysis.

SD: Standard Deviation. 
Elements such as vanadium $(\mathrm{V})$, cobalt $(\mathrm{Co})$, molybdenum (Mo) and chromium (Cr) were relatively in low concentrations or absent in the analysed fruit juices. These trace elements were found in the following ranges: from $0.23 \mu \mathrm{g} / \mathrm{L}$ (CHA1) to $12.50 \mu \mathrm{g} / \mathrm{L}$ (JUD3) for $\mathrm{V}$, from $0.58 \mu \mathrm{g} / \mathrm{L}$ (CHA4) to $17.10 \mu \mathrm{g} / \mathrm{L}$ (JUD3) for $\mathrm{Co}$, and finally from $1.17 \mu \mathrm{g} / \mathrm{L}$ (CHA4) to 58.70 (CHA5) for $\mathrm{Mo}$, and $1.40 \mu \mathrm{g} / \mathrm{L}$ (FRE4) to $70.50 \mu \mathrm{g} / \mathrm{L}$ ) for $\mathrm{Cr}$. Mean values were $1.24 \mu \mathrm{g} / \mathrm{L}$, $18.26 \mu \mathrm{g} / \mathrm{L}, 5.95 \mu \mathrm{g} / \mathrm{L}, 24.74 \mu \mathrm{g} / \mathrm{L}$ and $15.23 \mu \mathrm{g} / \mathrm{L}$ for $\mathrm{V}, \mathrm{Co}$, $\mathrm{Mo}$ and $\mathrm{Cr}$ respectively.

A classification of the elements in descending order of the concentrations gives $\mathrm{Mg}>\mathrm{Ca}>\mathrm{Mn}>\mathrm{Fe}>\mathrm{Cu}>\mathrm{Zn}>\mathrm{Ni}$ for the major and minor elements and $\mathrm{Mo}>\mathrm{Cr} \mathrm{Co}>\mathrm{V}$ for the trace elements. These results are consistent with a synthesis of scientific results from different authors $[3,4,6,9,10,13,14$, 17] who obtained the ranges of concentrations of the following elements: $\mathrm{Mg}(7000 \mu \mathrm{g} / \mathrm{L}-750000 \mu \mathrm{g} / \mathrm{L}) ; \mathrm{Ca}$ $(140 \mu \mathrm{g} / \mathrm{L}-980100 \mu \mathrm{g} / \mathrm{L}), \mathrm{Mn}(60 \mu \mathrm{g} / \mathrm{L}-23000 \mu \mathrm{g} / \mathrm{L}) ; \mathrm{Fe}$ $(9 \mu \mathrm{g} / \mathrm{L}-179200 \mu \mathrm{g} / \mathrm{L}) ; \mathrm{Ni}(40 \mu \mathrm{g} / \mathrm{L}-73370 \mu \mathrm{g} / \mathrm{L}) ; \mathrm{Cu}(\mathrm{ND}-$ $490 \mu \mathrm{g} / \mathrm{L}) ; \quad \mathrm{Cr}(\mathrm{ND}-2767 \mu \mathrm{g} / \mathrm{L})$ and $\mathrm{Zn} \quad(40 \mu \mathrm{g} / \mathrm{L} \quad-$ $545900 \mu \mathrm{g} / \mathrm{L})$ where ND means "not detected".

The mean concentration of $\mathrm{Mg}$ was close to that obtained by [9], whereas that of $\mathrm{Zn}$ was close to the value obtained by [10] in pineapple juices but widely differed from those of [11]. The highest grades were obtained by [11] for Fe, Ni and $\mathrm{Zn}$. Concentrations for $\mathrm{Ni}$ were slightly lower in commercial pineapple juices from Benin whereas $\mathrm{Cu}$ shows slightly higher values compared to the literature with the exception of
[8] which obtained a high value $(2910 \mu \mathrm{g} / \mathrm{L})$ for grape juice cultivated according to biological processes.

All things considered, the major elements ( $\mathrm{Mg}$ and $\mathrm{Ca})$ and the minor elements with $\mathrm{Mn}$ and $\mathrm{Fe}$ at the upper end were strongly present in the juices. The mean value of $\mathrm{Ni}$ (which was equal to the median) was greater than the maximum value of the literature $[3,4,5,6,9,10]$.

On the other hand, the $\mathrm{Ca}$ and $\mathrm{Mg}$ content were higher than those obtained by [8] in grape juice, the same was true for $\mathrm{Fe}, \mathrm{Mn}$ and $\mathrm{Zn}$. On the other hand, $\mathrm{Cu}$ values were lower than those obtained by [8]

The concentrations of $\mathrm{Ca}$ were generally distributed around the median value $(219500 \mu \mathrm{g} / \mathrm{L})$ which was close to the mean value $(223616 \mu \mathrm{g} / \mathrm{L})$ with the exception of JUD2 $(593000 \mu \mathrm{g} / \mathrm{L}), J U D 3788000 \mu \mathrm{g} / \mathrm{L})$ and VIP3 $(755000 \mu \mathrm{g} / \mathrm{L})$ which were well above the two reference values (Figure 2).

The distribution of $\mathrm{Mg}$ concentrations around the median $(201000 \mu \mathrm{g} / \mathrm{L})$ and the mean $(193558 \mu \mathrm{g} / \mathrm{L})$ was more uniform than that of $\mathrm{Ca}$. Some samples slightly deviate JUA1 $(278000 \mu \mathrm{g} / \mathrm{L}), \mathrm{CHA} 1(268000 \mu \mathrm{g} / \mathrm{L}), \mathrm{CHA} 2(276000 \mu \mathrm{g} / \mathrm{L})$ and OJA4 $(273000 \mu \mathrm{g} / \mathrm{L})$ at the upper end of the mustache box and JAF1 the lower end of the mustache box (Figure 2). The best rates of Mn (Figure 3) could be explained by the processes applied by the FRU unit which displays the highest Mn values for FRU4, FRU5 and FRU6, with the respective concentrations $25225 \mu \mathrm{g} / \mathrm{L}, 25344 \mu \mathrm{g} / \mathrm{L}$ and $24981 \mu \mathrm{g} / \mathrm{L}$, followed closely by VIB juice (VIB2, 19950 $\mu \mathrm{g} / \mathrm{L}$ ) while the median value was $8707 \mu \mathrm{g} / \mathrm{L}$ and the mean value was $5811 \mu \mathrm{g} / \mathrm{L}$.

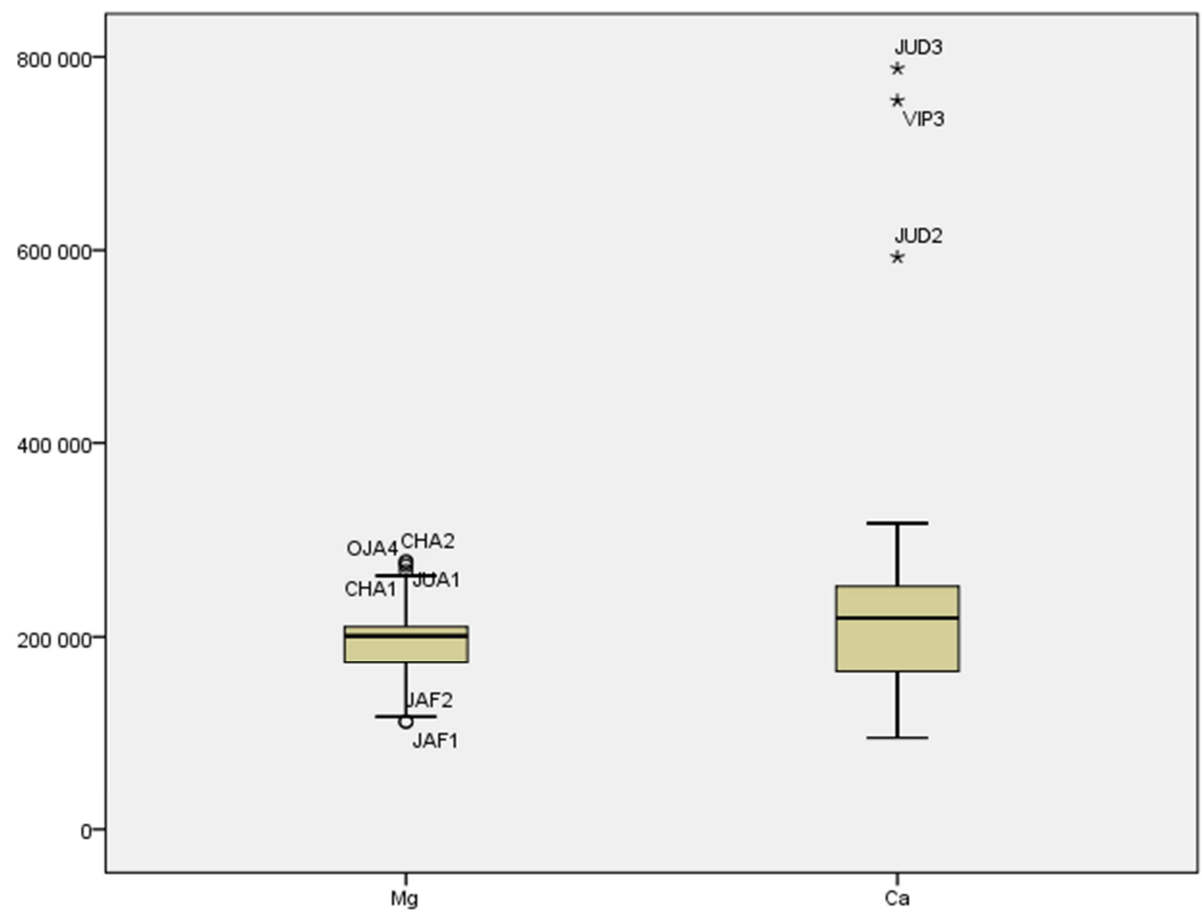

Figure 2. Mustache box representation of macro-element concentrations (Ca and $\mathrm{Mg}$ ).

These strong variations in concentrations could be attributed to juice production processes. Indeed, [6] have noted that laboratory-extracted juices generally contain less $\mathrm{Mn}$ than commercially purchased juices and attribute this to extraction processes rather than the acidity of the soils on which the fruits were grown.

Fe concentrations in juices produced by the OJA unit (Figure 3) vary from $41635 \mu \mathrm{g} / \mathrm{L}$ (for OJA2) to $85612 \mu \mathrm{g} / \mathrm{L}$ 
(for OJA1) and were significantly higher than those of other processing units; the third quartile $(2606 \mu \mathrm{g} / \mathrm{L})$ was much lower (Table 3). All juices in this unit (OJA) exceeded the threshold of $50,000 \mu \mathrm{g} / \mathrm{L}$ prescribed by the beverage quality standards with the exception of OJA2 (Figure 3).

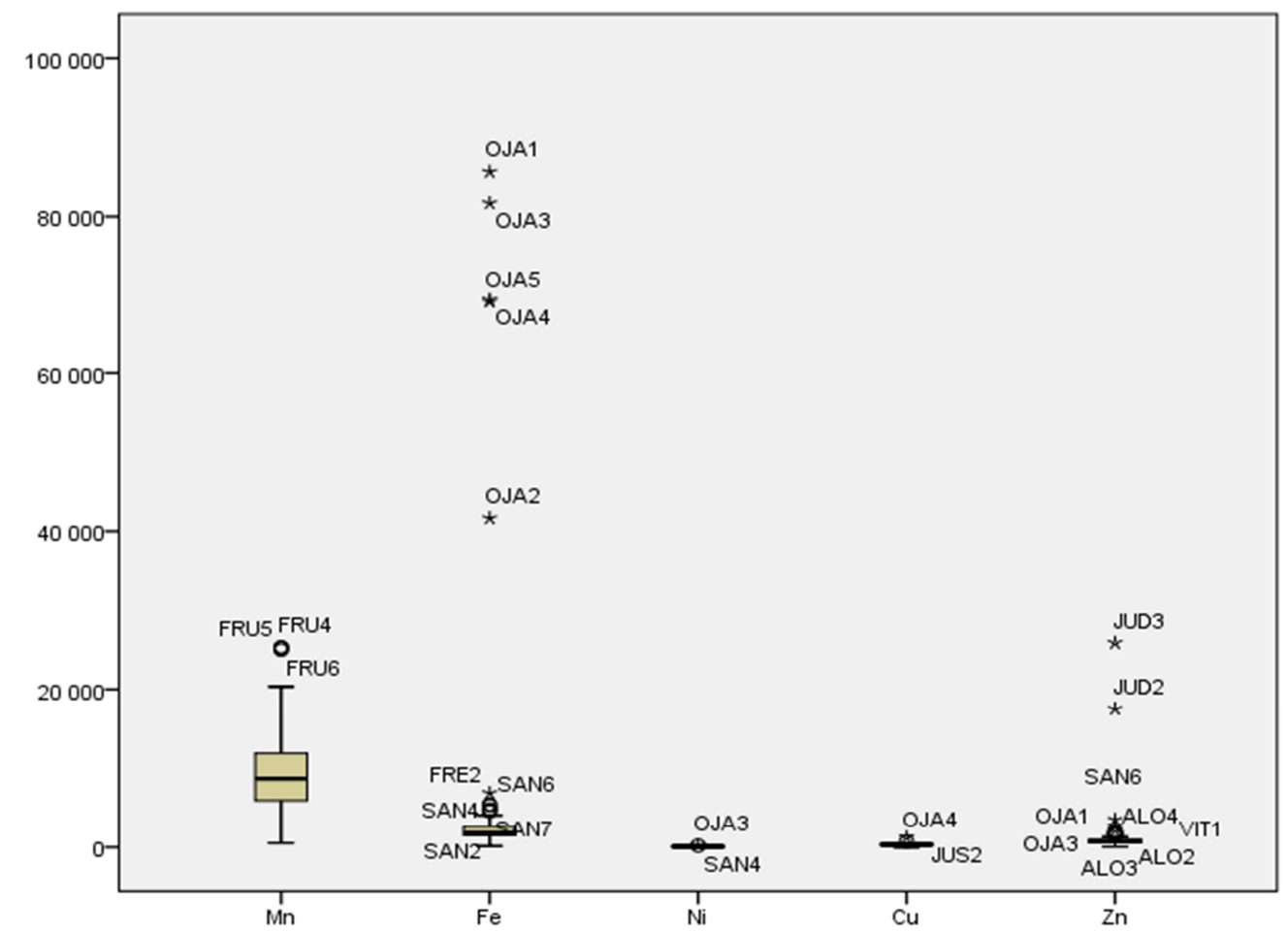

Figure 3. Box-mustache representation of micronutrient concentrations ( $\mathrm{Mn}, \mathrm{Fe}, \mathrm{Ni}$, Cu and $254 \mathrm{Zn}$ ).

Although Zn levels were relatively low, we observed a heterogeneity of concentrations with JUD2 and JUD3 $(17508 \mu \mathrm{g} / \mathrm{L}$ and $25862 \mu \mathrm{g} / \mathrm{L}$ respectively) well above the average $(1313 \mu \mathrm{g} / \mathrm{L})$, followed by SAN6, OJA3 and OJA1 $(3501 \mu \mathrm{g} / \mathrm{L}, 1649 \mu \mathrm{g} / \mathrm{L}$ and $2627 \mu \mathrm{g} / \mathrm{L})$ while the 3 rd quartile ( $75 \%$ of the values were below this value) is $969 \mu \mathrm{g} / \mathrm{L}$. The relatively low concentration $\mathrm{Ni}$ and $\mathrm{Cu}$ elements were more homogeneous in pineapple juices with an average of $80 \mu \mathrm{g} / \mathrm{L}$ and $341 \mu \mathrm{g} / \mathrm{L}$ respectively and a median of $80 \mu \mathrm{g} / \mathrm{L}$ and $325 \mu \mathrm{g} / \mathrm{L}$ respectively (Table 3$)$. Except OJA3 $(253 \mu \mathrm{g} / \mathrm{L})$ and SAN4 $(196 \mu \mathrm{g} / \mathrm{L})$ for $\mathrm{Ni}$ and OJA4 $(4541 \mu \mathrm{g} / \mathrm{L})$ and JUS2 $(1256 \mu \mathrm{g} / \mathrm{L})$ for $\mathrm{Cu}$ which deviate from the mean and median, all other samples have concentrations concentrated around these two values.

In conclusion Benin's pineapple juices were rich in minerals and especially in $\mathrm{Ca}, \mathrm{Mg}, \mathrm{Mn}$ and Fe. These juices could be used to improve nutritional health in all social strata. Indeed, various authors have shown that maternal and infant mortality and morbidity are directly or indirectly related to malnutrition related to mineral deficiency $[11,12]$. The antioxidant properties of certain minerals contained in the fruit juices help protect human health from free radical damage and oxidative stress, and thereby prevent cardiovascular or degenerative diseases, as well as certain cancers. The mineral elements exert primordial functions in the biochemical processes of the organism: they regulate the metabolism, facilitate the release of energy and ensure important functions in the synthesis of bones and tissues $[11,12,13,14]$.
Micronutrient deficiency is a dangerous form of malnutrition caused by insufficient intake of essential vitamins and minerals. About 30 minerals are known to be essential for life and pineapple juices contain plenty of them. While some of them such as $\mathrm{Ca}, \mathrm{Mg}$ are needed in more or less significant quantities (macronutrients), others are in the order of trace or ultra-trace (trace elements). Elements such as $\mathrm{Cu}, \mathrm{Fe}, \mathrm{Ni}, \mathrm{Zn}$ and $\mathrm{Mn}$ were at the upper end of this scale of trace elements and play an important role in biological systems. This was the case of the chemical elements V, Mo, $\mathrm{Cr}$ and $\mathrm{Co}$ which are necessary to smaller proportions compared to the first ones. The concentrations of these elements in the different samples were low $(<80 \mu \mathrm{g} / \mathrm{L})$ but were not uniform from one unit to another; they vary from $0.23 \mu \mathrm{g} / \mathrm{L}$ (CHA1) to $12.50 \mu \mathrm{g} / \mathrm{L}$ (JUD3) for $\mathrm{V}, 1.40 \mu \mathrm{g} / \mathrm{L}$ (FRE4) to $70.50 \mu \mathrm{g} / \mathrm{L}$ (FRU3) for $\mathrm{Cr}, 0,58 \mu \mathrm{g} / \mathrm{L}(\mathrm{CHA} 4)$ to $17.10 \mu \mathrm{g} / \mathrm{L}$ (JUD3) for Co and from $1.17 \mu \mathrm{g} / \mathrm{L}$ (CHA4) to $58.70 \mu \mathrm{g} / \mathrm{L}$ (CHA5) for Mo (Table 4). However, some units were distinguished by relatively higher values than others (Figure 4). This was JUD2 and JUD3 for the V and Co, OJA1, OJA3 and OJA4 for the Co, JUS1 and JUS3 for the Cr and CHA6 and CHA5 for the Mb. In isolation we can add to this list FRE2 and JUA2 for the V and ALA1 for the Co.

The ranges of concentrations were in the same order of magnitude compared to previous work $[3,4,5,6,9,10]$ except [5] which recorded for $\mathrm{Cr}$ values of $2767 \mu \mathrm{g} / \mathrm{L}$ and [15], who obtained a value of $370 \mu \mathrm{g} / \mathrm{L}$ for Co. However, for $\mathrm{V}$, [7] recorded $5 \mu \mathrm{g} / \mathrm{L}$ whereas [15] obtained $52 \mu \mathrm{g} / \mathrm{L}$. 


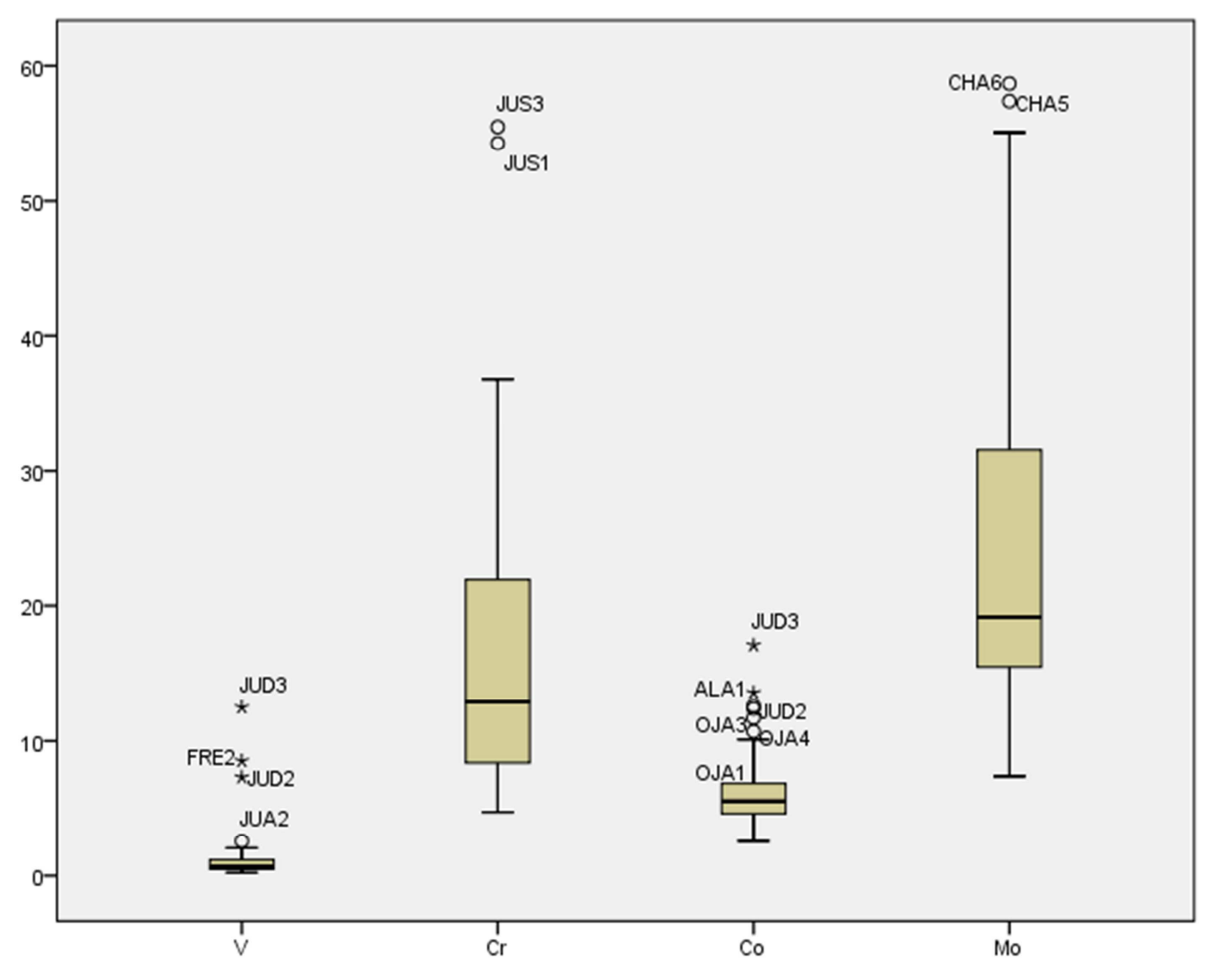

Figure 4. Box-mustache representation of trace element concentrations.

The average daily requirements for mineral elements are presented in Table below 5, showing a coherence of nutritional requirements with the composition of pineapple juices in mineral elements.

Table 5. The average daily needs in mineral elements.

\begin{tabular}{lllllllllllll}
\hline Elements & $\mathbf{M g}$ & $\mathbf{C a}$ & $\mathbf{M n}$ & $\mathbf{F e}$ & $\mathbf{C o}$ & $\mathbf{C u}$ & $\mathbf{Z n}$ & $\mathbf{S e}$ & $\mathbf{V}$ & $\mathbf{N i}$ & $\mathbf{C r}$ & $\mathbf{M o}$ \\
\hline $\mathrm{RDI}(\mathrm{mg})$ & 310 & 1000 & 10 & 18 & 2 & 0.9 & 8 & 8 & 1.5 & 0.25 & 0.025 & 0.034 \\
\hline
\end{tabular}

RDI: Recommended daily intake

According to the classification of minerals, the macroelements are those needed in quantity greater than $50 \mathrm{mg} /$ day, among these are calcium and magnesium. The trace elements are those needed in quantity less than $50 \mathrm{mg}$ /day, namely: iron, zinc, copper, manganese, molybdenum, etc. The data obtained show that the consumption of pineapple juice at the rate of one litre per day distributed between meals would effectively meet the daily needs of minerals. Because of the large amounts of essential and physiologically important elements they contain, fruit juices often prove to be rich sources of nutrients and valuable dietary supplements in the event of mineral deficiencies [3, 7, 11, 13-16]. Considering the total concentrations of elements, some studies relating to the elementary analysis of fruit juices reveal that the daily consumption of fruit juice can clearly shelter from the recommended daily doses (RDI) for certain nutritionally important elements required for infants, children, pregnant women and adults $[13,15,17,18]$.

\subsection{Comparative Analysis of Minerals in Commercial Juices from Benin and France}

One of the objectives of this research was to analyse the average concentrations per unit of production in order to study the compliance of Benin's juices with international standards with reference values the concentrations of juices sampled in France and analysed in the same conditions. Tables 6 and 7, related to the variation of the composition of juices in minerals according to the production units, present the averages of the results of the analyses by unit of manufacture, by country and the general average of the concentrations in minerals. Overall, the concentrations of macro-elements, micro-elements and trace elements in the juices of Benin units were above these reference values except for Mn. This could be the consequence of the high Brix value which represent the dry matter content and which shows that French commercial juices have been diluted. The reversal of the trend for $\mathrm{Mn}$ can be seen through the average concentration of $\mathrm{Mn}$ in Benin juices equal to $9472 \mu \mathrm{g} / \mathrm{L}$, which was lower than that in French commercial juices, which was $11343 \mu \mathrm{g} / \mathrm{L}$ and the average which was equal to $9551 \mu \mathrm{g} / \mathrm{L}$. This is explained by the high values of this element in commercial VIB juice from France with an average of $19631 \mu \mathrm{g} / \mathrm{L}$, which was closely followed by FRU juice from Benin with an average of $18515 \mu \mathrm{g} / \mathrm{L}$. Moreover, the vanadium level in the juices was less than $10 \mu \mathrm{g} / \mathrm{L}$, the Cobalt $15 \mu \mathrm{g} / \mathrm{L}$ and the Molybdenum $50 \mu \mathrm{g} / \mathrm{L}$ except the 
TROP juices with an average molybdenum content of $53.55 \mu \mathrm{g} / \mathrm{L}$. It should also be noted that the FRU juice contains practically no vanadium (the content of which was below the threshold of quantification).

\subsection{Analysis of the Homogeneity of Commercial Juices in Relation to Mineral Composition}

The homogeneity analysis will consist in studying the variability of the results averages of the quantitative analysis of minerals and sugar levels around the median value for the juices of each unit of production in relation to the sampling parameters, the date of production, the area of cultivation and/or production of the juice, which were generally close, will also be discussed. According to [17], pineapple growing areas in Benin are located in five of the eight Atlantic townships of the Atlantic Department. The same was true of exporters and intermediaries who were located in the pineapple growing areas in the five townships of Abomey-
Calavi, Zè, Allada, Tori and Toffo. Wholesalers and retailers were based in five markets: SèmèKraké (in Sèmè-Kpodji), Dantokpa (in Cotonou), Zè, Sékou (Allada) and Sèhouè (Toffo). Sèmè-Kraké and Dantokpa are the main sources of supply for the regional market since they are often visited by local and regional customers from Nigeria, Ghana, Burkina Faso, Mali and Côte-d'Ivoire. The fruit and juice pineapple processors are located in the Atlantic and Littoral Departments; but most of them are not located in the pineapple producing areas, but in the Littoral Department near the regional markets. Table 7 related to the variations in the composition of commercial juices and syrups in mineral elements as a function of the location of the production units shows that the pineapples fruits used in Porto-Novo are very rich in $\mathrm{Zn}$ and those of Allada district are particularly rich in Fe. This shows that the nature of the soils of the growing regions influences the composition of the major minerals and micro-elements of the produced juices (Table 9).

Table 6. Variations in the composition of commercial juices and syrups in mineral elements according to the production units from.

\begin{tabular}{|c|c|c|c|c|c|c|c|c|c|c|c|c|}
\hline \multirow{2}{*}{$\begin{array}{l}\text { Variables } \\
(\mu \mathrm{g} / \mathrm{L})\end{array}$} & \multicolumn{12}{|c|}{ JUICE MANUFACTURING UNITS (LABEL) } \\
\hline & ALA & ALO & BRA & CHA & FRE & FRU & INN** & $\mathbf{J A F} * *$ & JUA & JUD & JUS & JUV \\
\hline \multicolumn{13}{|c|}{ Macro-elements } \\
\hline $\mathrm{Mg}$ & 230500 & 217500 & 207333 & 227667 & 150200 & 195833 & 117500 & 111667 & 193333 & 200667 & 200667 & 165000 \\
\hline $\mathrm{Ca}$ & 231000 & 239000 & 248000 & 241667 & 150400 & 263500 & 129000 & 95833 & 156500 & 525333 & 227000 & 168167 \\
\hline \multicolumn{13}{|c|}{ Micro-elements } \\
\hline $\mathrm{Mn}$ & 11631 & 6072 & 9369 & 8336 & 3215 & 18515 & 5289 & 9110 & 10480 & 10868 & 15374 & 7543 \\
\hline $\mathrm{Fe}$ & 1714 & 1327 & 2321 & 1543 & 2138 & 3048 & 1967 & 1576 & 1972 & 3024 & 2491 & 1269 \\
\hline $\mathrm{Ni}$ & 115 & 58 & 50 & 68 & 44 & 130 & 30 & 28 & 116 & 88 & 98 & 65 \\
\hline $\mathrm{Cu}$ & 419 & 276 & 290 & 272 & 295 & 372 & 378 & 404 & 370 & 476 & 649 & 242 \\
\hline $\mathrm{Zn}$ & 703 & 1099 & 645 & 605 & 61 & 643 & 1107 & 986 & 673 & 14745 & 1044 & 755 \\
\hline \multicolumn{13}{|c|}{ Trace elements } \\
\hline V & 0.35 & 0.43 & 0.49 & 1.4 & 3.96 & $<\mathrm{QL}^{*}$ & 0.64 & 0.92 & 1.39 & 7.27 & 1.23 & 0.61 \\
\hline $\mathrm{Cr}$ & 10.41 & 10.34 & 10.94 & 6.18 & 3.77 & 64.97 & 15.7 & 9.21 & 7.03 & 24.47 & 43.17 & 6.62 \\
\hline $\mathrm{Co}$ & 8.80 & 5.37 & 4.83 & 4.31 & 4.65 & 6.09 & 4.66 & 5.13 & 6.98 & 12.53 & 7.12 & 4.75 \\
\hline Mo & 11.65 & 16.07 & 32.10 & 28.66 & 13.24 & 41.92 & 13.10 & 10.40 & 19.68 & 31.23 & 30.8 & 17.48 \\
\hline
\end{tabular}

* Lower than the threshold of quantification ** Juices from France

The one-way ANOVA model was used for statistical processing, and the calibrated averages were significant at $\mathrm{p}<0.001\left(32 \%<\right.$ adjusted $\left.\mathrm{R}^{2}<59 \%\right)$ except for Fe 385 with adjusted $\mathrm{R}^{2}=93.05 \%$.

Table 7. Variations in the composition of commercial juices and syrups in mineral elements according to production units.

\begin{tabular}{|c|c|c|c|c|c|c|c|c|c|c|c|c|}
\hline \multirow{2}{*}{$\frac{\text { Variables }}{(\mu \mathrm{g} / \mathrm{L})}$} & \multicolumn{9}{|c|}{ Juice Production Units } & \multicolumn{2}{|c|}{ Average/country } & \multirow{2}{*}{ OverallAverage } \\
\hline & LAS & OJA & PAS & SAN & SYR** & TRO & VIB* & VIP & VIT & BEN & FR & \\
\hline \multicolumn{13}{|c|}{ Macro-elements } \\
\hline $\mathrm{Mg}$ & 240333 & 223800 & 193167 & 216333 & 141667 & 175000 & 173500 & 171429 & 198167 & 198827 & 134222 & 193558 \\
\hline $\mathrm{Ca}$ & 244333 & 257400 & 160333 & 244778 & 143667 & 270500 & 169000 & 257000 & 205500 & 231784 & 131278 & 223616 \\
\hline \multicolumn{13}{|c|}{ Micro-elements } \\
\hline $\mathrm{Mn}$ & 12995 & 11856 & 7966 & 4756 & 3865 & 14166 & 19631 & 9247 & 11819 & 9472 & 11343 & 9551 \\
\hline $\mathrm{Fe}$ & 1335 & 69496 & 1519 & 4276 & 1517 & 2098 & 2359 & 2147 & 1345 & 6156 & 1967 & 5811 \\
\hline $\mathrm{Ni}$ & 76 & 121 & 76 & 95 & 49 & 99 & 23 & 83 & 75 & 84 & 27 & 80 \\
\hline $\mathrm{Cu}$ & 333 & 486 & 360 & 416 & 122 & 431 & 509 & 197 & 324 & 347 & 430 & 341 \\
\hline $\mathrm{Zn}$ & 720 & 1597 & 770 & 1324 & 558 & 854 & 926 & 491 & 986 & 1349 & 1006 & 1313 \\
\hline \multicolumn{13}{|c|}{ Trace elements } \\
\hline V & 0.57 & 1.14 & 0.34 & 1.41 & 1.26 & 0.55 & 1.06 & 1.35 & 0.57 & 1.44 & 1.12 & 1.22 \\
\hline $\mathrm{Cr}$ & 5.9 & 27.28 & 16.72 & 18.99 & 36.8 & 9.79 & 11.05 & 21.42 & 16.75 & 18.99 & 11.99 & 17.98 \\
\hline $\mathrm{Co}$ & 7.48 & 10.6 & 6.8 & 4.48 & 2.55 & 3.97 & 3.00 & 6.15 & 5.42 & 6.49 & 6.02 & 5.97 \\
\hline Mo & 19.10 & 21.62 & 14.40 & 40.50 & 7.39 & 53.55 & 12.65 & 24.84 & 21.00 & 25.76 & 23.87 & 24.74 \\
\hline
\end{tabular}

BEN: Benin country

FR: France country *Samples from France **Syrup sample 
Table 8. Variations in the composition of commercial juices and syrups in mineral elementsaccording to the location of the production units.

\begin{tabular}{|c|c|c|c|c|c|c|c|c|c|}
\hline \multirow{2}{*}{ Townships/districts } & \multirow{2}{*}{ Ns } & \multicolumn{7}{|c|}{ Concentrations (in $\mu \mathrm{g} / \mathrm{L}$ ) } & \multirow{2}{*}{ Average (Brix) } \\
\hline & & Mg & $\mathbf{C a}$ & Mn & $\mathbf{F e}$ & $\mathrm{Ni}$ & $\mathrm{Cu}$ & $\mathbf{Z n}$ & \\
\hline ABOMEY & 6 & 193333 & 156500 & 10480 & 1972 & 116 & 370 & 673 & 14.8 \\
\hline AKASSATO & 6 & 207333 & 248000 & 9369 & 2321 & 50 & 290 & 645 & 14.7 \\
\hline ALLADA & 13 & 218077 & 252154 & 10587 & 27764 & 93 & 379 & 1025 & 14.3 \\
\hline AVAKPA & 9 & 216333 & 244778 & 4756 & 4061 & 93 & 369 & 1278 & 16.0 \\
\hline CALAVI & 8 & 202500 & 178000 & 8883 & 1567 & 85 & 375 & 753 & 12.7 \\
\hline COME & 6 & 165000 & 168167 & 7543 & 1269 & 65 & 242 & 755 & 12.7 \\
\hline COTONOU & 7 & 171429 & 257000 & 9247 & 2147 & 83 & 197 & 491 & 13.1 \\
\hline EKPE & 6 & 217500 & 239000 & 6072 & 1327 & 58 & 276 & 1099 & 15.2 \\
\hline FR & 6 & 134222 & 131278 & 11343 & 1967 & 27 & 370 & 1006 & 11.6 \\
\hline LOGBOZOUKPA & 6 & 195833 & 263500 & 18515 & 3048 & 130 & 372 & 643 & 14.1 \\
\hline PORTO-NOVO & 9 & 177037 & 285815 & 6852 & 2344 & 62 & 359 & 5335 & 13.1 \\
\hline SEKOU & 3 & 200667 & 227000 & 15374 & 2491 & 98 & 649 & 1044 & 13.7 \\
\hline SYR* (ABOMEY) & 1 & 141667 & 143667 & 3865 & 1517 & 49 & 122 & 558 & 12.6 \\
\hline $\mathrm{ZE}$ & 6 & 198167 & 205500 & 11819 & 1345 & 75 & 324 & 986 & 15.3 \\
\hline
\end{tabular}

Ns: Number of samples collected. * Syrup was manufactured in Abomey

Table 9. Presentation of the samples with their identification codes.

\begin{tabular}{lll}
\hline TOWN/COUNTRY & Ns & SAMPLES IDENTIFICATION NAME \\
\hline ABOMEY & 7 & JUA1- JUA6, SYR \\
AKASSATO & 6 & BRA1- BRA6, \\
ALLADA & 13 & CHA1- CHA6, OJA1- OJA5, TRO1- \\
AVAKPA & 9 & SAN1- SAN9 \\
CALAVI & 8 & ALA1- ALA2, PAS1- PAS6 \\
COME & 6 & JUV1- JUV6 \\
COTONOU & 7 & VIP1-VIP7 \\
EKPE & 6 & ALO1- ALO6 \\
FRANCE & 6 & JAF1- JAF2, INN1- INN2, VIB1- VIB2 \\
LOGBOZOUKPA & 6 & FRU1- FRU6 \\
PORTO-NOVO & 9 & FRE4- FRE5, LAS, JUD1- JUD3 \\
SEKOU & 3 & JUS1- JUS3 \\
ZE & 6 & VIT1- VIT6 \\
TOTAL & 92 & \\
\hline
\end{tabular}

Ns: Number of samples

In general, juices manufactured in urban areas, far from production sites, were characterized by the lowest sugar levels at the limit of the required threshold (Table 8). These are the cities of Cotonou (13.1 Brix), Porto-Novo (13.1 Brix), Abomey-Calavi (12.7 Brix) and Comé (12.7 Brix) unlike rural areas such as AVAKPA (16.0 Brix). The juice production units of these localities proceeds either to systematic Brix corrections or the fruits were affected by the conditions of transport and conservation before processing into juice. This thesis of degradation of the quality and especially of the sugars the atomic links of which were destroyed is more concordant for several reasons. According to Hotegni et al. $[11,12,17,20]$ the poor transportation system and poor storage conditions at the wholesaler and processor level and the lack of transport crates would be one of the major causes of significant fruit loss. According to these authors, pineapple is delivered under uncontrolled conditions in "taxis" or "bachées" by independent drivers hired by buyers. Also, fruits were exposed to sunlight for a few hours, loading in trucks side by side and unconditioned transport conditions would affect fruit quality Crisosto et al.,
1995 cited by [7]. However, it is well known that temperature conditions affect the shelf life of fruit Nunes and Edmond 2002 in [7]. According to [12], the optimal storage temperature for a long shelf life of pineapple is $10{ }^{\circ} \mathrm{C}$ while the ambient temperature in the region fluctuates between $25^{\circ} \mathrm{C}$ and $31^{\circ} \mathrm{C}$.

\section{Conclusion}

Globally, the major elements $(\mathrm{Mg}$ and $\mathrm{Ca}$ ) and the minor elements $(\mathrm{Mn}, \mathrm{Fe}, \mathrm{Ni}, \mathrm{Cu}, \mathrm{Zn})$ were strongly present in pineapple juices made in Benin. For all juice samples, Mn and $\mathrm{Fe}$ were the most quantitatively represented microelements, while $\mathrm{Ni}, \mathrm{Cu}$ and $\mathrm{Zn}$ were weakly detected, with the exception of juice of the JUAN unit where $\mathrm{Zn}$ is strongly detected. It is noted that the soils of culture have a determining role in the composition of the juices as well as the conditions of transport which would affect the quality of the juices, particularly with regard to the low level of Brix degree.

The basic analysis shows that fruit juices in Benin have a varied mineral composition with very high levels of certain elements in some regions. These juices could be used as dietary supplements [8] to stem malnutrition and improve nutritional health in all social strata.

Trace and minor elements such as $\mathrm{Co}, \mathrm{Cr}, \mathrm{Cu}, \mathrm{Ni}, \mathrm{Zn}$ and Se contained in juices do not contribute significantly to nutritional requirements. The process of concentrating to obtain pineapple syrup appears to cause a loss of sugars and a significant variation in mineral concentrations either by loss or gain. Further work may be carried out in the direction of controlling these factors of influence on the nutritional quality of pineapple juices and syrups.

\section{Acknowledgments}

We gratefully acknowledge the advice and assistance of Andrew A. Erakhrumen, $\mathrm{PhD} /$ Department of Forest Resources and Wildlife Management/Faculty of Agriculture, University of Benin, Benin City, Nigeria. 


\section{References}

[1] Institut National de la Statistique et de l'Analyse Economique (INSAE), Recensement général de la population, CotonouBénin, 2007.

[2] Ministère de l'Agriculture, de l'Elevage et de la Pêche (MAEP), Rapport sur l'Ananas au Bénin, 2010.

[3] Szymczycha-Madeja, A.; Welna, M; Jedryczko, D.; Pohl P., Developments and strategies in the spectrochemical elemental analysis of fruit juices, Trends in Analytical Chemistry 2014. 55 pp. $68-80$.

[4] Achigan-Dako, E. G.; Adjé, C. A.; N'Danikou, S.; Fassinou Hotegni, N. V.; Agbangla, C. and Ahanchédé, A., Drivers of conservation and utilization of pineapple genetic resources in Benin, SpringerPlus, 2014. 3:273, pp. 1-11. http://www.springerplus.com/content/3/1/273

[5] Francisco, J. A. P.; Raquel, P. F.; Cruz-lopes, G. L., Effects of pre- and post-harvest factors on the selected elements contents in fruit juices, Czech J. Food Sci. 2015, 33, 201 (4) pp. 384 391.

[6] McHard, J. A.; Winefordner, J. D. and Ting, Sik-Vung, Atomic Absorption Spectrometric Determination of Eight Trace Metals in Orange Juice following Hydrolytic Preparation, J. Agric. Food Chem. 1976, Vol. 24, No. 5, pp 950-953.

[7] Santos Froes, R. E.; Neto, W. B.; Couto Silva, N. O.; Naveira, R. L. P.; Nascentes, C. C.; da Silva, J. B. B, Multivariate optimization by exploratory analysis applied to the determination of microelements in fruit juice by inductively coupled plasma optical emission spectrometry, Spectrochimica Acta Part B 64 (2009) pp. 619-622.

[8] Miele, A.; Rizzdn, L. A., Nascimento de Queirdz, S. C. do; Gianelld, C, Physicochemical composition, minerals, and pesticide residues in organic grape juices. Food Science and Technology, 2014. DDI: http://dx.doi.org/10.1590/1678457X.6540. ISSN 0101-2061

[9] Camara, M.; Diez, C. and Torija, E., Chemical characterization of pineapple juices and nectars. Principal component analysis, Food Chemistry 1995. 54 pp. 93-100.

[10] Akan, B. W.; Olusegun, O. A.; Adekunle, F. O., Trace metal levels in fruit juices and carbonated beverages in Nigeria.
Environ Monit Assess, 2009. 156: 303-306 DOI 10. 1007/s10661-008-0485-1.

[11] Fassinou Hotegni, V. N.; Lommen, W. J. M.; Van der Vorst, J. G. A. J., Agbossou, E. K. and Struik, P. C., Analysis of Pineapple Production Systems in Benin, Eds.: J.-N. Wünsche and L. G. Albrigo, Acta Hort. 2012. 928, ISHS pp. $47-58$.

[12] Fassinou Hotegni, V. N.; Lommen, W. J. M.; Agbossou, E. K. and Struik, P. C., Influence of weight and type of planting material on fruit quality and its heterogeneity in pineapple [Ananas comosus (L.), 2016. Volume5 Article798 pp. 1 -16.

[13] World Health Organization (WHO), Expert Committee on Trace Metals in Human Nutrition. World Health Organization Tech. Rep. Ser. No. 532, 1973.

[14] World Health Organization (WHO), Trace Elements in human nutrition and health, Geneva, 1996.

[15] Tormen, L., Placido Torres, D.; Dittert, I. M.; Arau' jo, R. G. O., Frescura, V. L. A.; Jose' Curtius, A., Rapid assessment of metal contamination in commercial fruit juices by inductively coupled mass spectrometry after a simple dilution, Journal of Food Composition and Analysis 2011. 24 pp. 95-102.

[16] Perez, A. L.; Smith, B. W. and Anderson, K. A., Stable isotope and trace element profiling combined with classification models to differentiate geographic growing origin for three fruits: Effects of Subregion and Variety, J. Agric. Food Chem. 2006, 54, pp. 4506 - 4516.

[17] Fassinou Hotegni, N. V.; Lommen, W. J. M.; Van der Vorst, J. G. A. J.; Agbossou E. K. and Struik, P. C., Bottlenecks and Opportunities for Quality Improvement in Fresh Pineapple Supply Chains in Benin, International Food and Agribusiness Management Review, 2014. Volume 17 Issue 3, pp. 139 170.

[18] World Health Organization (WHO), Safety Evaluation of certain food additives and contaminants; Tin. WHO Food Additives Series No. 46. Joint FAO/WHO, 2001.

[19] https://s3.amazonaws.com/publicinspection.federalregister.gov/2016-11867.pdf (pages 903904)

[20] Fassinou Hotegni, V. N., Lommen, W. J. M.; Agbossou E. K. and Struik, P. C., Understanding the effects of slip pruning on pineapple fruit quality, Acta Hortic. 2016. 1111. ISHS. DOI Eds.: J.-N. Wünsche and L. G. Albrigo Acta Hort. 928, ISHS 2012, pp. $231-240$. 